\title{
Hydrogen Gas Production in Kersen Leaf Extract (Muntingia calabura) Using Stainless Steel Electrode
}

\author{
Isana Supiah Yosephine Louise* Resti Bangun Pertika
}

\author{
Department of Chemistry Education Universitas Negeri Yogyakarta \\ *Corresponding author. Email: isana_supiah@uny.ac.id
}

\begin{abstract}
This research was conducted to study the influence of the addition of kersen leaf extract, to understand the variation of temperature effect, and to determine the optimum result of hydrogen production in the process of water electrolysis within the kersen leaf extract using voltammetry method. The use of voltammetry cyclic method in water electrolysis was performed by setting the sweeping rate $50 \mathrm{mV} / \mathrm{s}$. $\mathrm{NaHCO}_{3}$ solution is functioned as electrolyte solution with a concentration of $5 \mathrm{~g} / \mathrm{L}$. A media modification which is a kersen leaf extract was added with concentration variety of 0 ; 0,2; 0,04; 0,008; 0,0016; 0,00032; and $0,000064 \mathrm{~g} / \mathrm{ml}$ in temperature variety from $25^{\circ} \mathrm{C}, 35^{\circ} \mathrm{C}$, and $45^{\circ} \mathrm{C}$. The addition of media can increase hydrogen gas production. Hydrogen gas is produced higher at $45^{\circ} \mathrm{C}$ than it is at $25^{\circ} \mathrm{C}$ and $35^{\circ} \mathrm{C}$. An optimum condition is obtained from sample 4 with $0,008 \mathrm{~g} / \mathrm{ml}$ concentration.
\end{abstract}

Keywords: "Hydrogen gas, stainless steel electrode, cyclic voltammetry, kersen leaf extract"

\section{INTRODUCTION}

In daily activities, human are inseparable from the use of energy. It becomes an essential thing to fulfill human needs. The energy sources mostly come from fossil fuels, such as petroleum, coal, and natural gas. However, the availability of fossil fuels will eventually run out and cannot be renewed. This is contradicted with the growth of the society and will result in the depletion of energy sources. In 2015-2016, there was a decrease of petroleum reserves by $0.74 \%$, natural gas by $5.04 \%$, and coal by $11.8 \%$. The depletion of fossil fuels, the main energy material, will have a negative impact on human life. If this problem is not immediately resolved, an energy crisis can be occur. Utilization and development of renewable fuel sources is needed to be an alternative solution to the problem [13]. Hydrogen has the potential to lessen the dependence on fossil fuel use and to reduce pollution. The combustion process of hydrogen gas produces quite a lot of energy. In addition, the use of hydrogen is more environmentally friendly since it does not create a greenhouse effect [1].

Hydrogen is an energy carrier which is unavailable in the nature but can be obtained through several methods, including coal gasification, biomass, methanol electrolysis, and water electrolysis [2]. The simplest and easiest method to produce the hydrogen gas is the water electrolysis method. The energy produced from the breakdown of water molecules $\left(\mathrm{H}_{2} \mathrm{O}\right)$ is easily converted into electrical energy that does not polluting the environment. In other words, the use of the water electrolysis method to produce hydrogen gas is relatively safe and easy. The production process of hydrogen gas uses electrolysis method which has shortcomings namely the need for large enough energy and the need for supporting media or electrolytes to accelerate its reaction [9]. Therefore, further research is needed in order to obtain the maximum hydrogen gas production.

The use of electrodes is very important in the electrolysis method. Electrodes that are commonly used in the electrolysis process are carbon electrodes. Isana (2007) has conducted research related to the use of carbon in the electrolysis process of various beverage brands [4]. Isana's research (2009) shows the use of carbon in the electrolysis process still produces relatively low efficiency [5]. Carbon electrodes have a weakness that is not resistant to rust and brittle, so it needs to be replaced with other electrodes that are better [3]. The selection of electrodes is seen from their corrosion resistant properties so that these electrodes are not easily repaired during use. Stainless steel metal is one type of electrode that is often used in the electrolysis method. The electrodes used in this study 
are stainless steel electrodes type S-430 which are quite corrosion resistant. In the electrolysis process, there are several factors influenced the efficiency of some formed hydrogen gas, including catalysts, temperatures, pressures, types of electrodes, and mediators [15].

$\mathrm{NaHCO}_{3}$ as base catalyst has better ability than $\mathrm{NaOH}$ in the water electrolysis process [12]. The research on the splitting of $\mathrm{H}_{2} \mathrm{O}$ molecules is also modified with the addition of media. The addition of the dahlia pinnata tuber starch media proved to be able to increase the optimum hydrogen gas efficiency in addition of 9 grams of dahlia pinnata tuber starch per liter solution [10]. Natural media in the form of bitter melon flour has optimum conditions in producing hydrogen gas with the addition of $0.6 \%$ medium bitter melon which requires the smallest energy of $1 \mathrm{mV}$ and hydrogen gas production efficiency of $51.06 \%$ [8]. The influence of various natural media enhancements in the process of electrolysis to produce hydrogen continues to see the potential for wastewater as the raw material for the electrolysis process [7]. In this research, the media added is a kersen leaf extract. The kersen leaf extract is mixed with electrolyte solution. According to a research conducted by Kuntorini in 2013, kersen leaves contain flavonoids, saponins, triterpenes, steroids, and tannins [14]. Flavonoids and tannins can be used as a corrosion rate inhibitor [17]. The addition of kersen leaves extract is expected to produce optimum hydrogen gas efficiency.

\section{METHODOLOGY}

Materials that used were stainless steel electrode, $\mathrm{Pt}$ electrode, $\mathrm{Ag} / \mathrm{AgCl}$ electrode, kersen leaf extract, aquabides, $\mathrm{NaHCO}_{3}, \mathrm{NiSO}_{4} \cdot 6 \mathrm{H}_{2} \mathrm{O}, \mathrm{Co}\left(\mathrm{NO}_{3}\right)_{2} \cdot 6 \mathrm{H}_{2} \mathrm{O}$, $\mathrm{FeSO}_{4} .7 \mathrm{H}_{2} \mathrm{O}, \mathrm{NaCl}, \mathrm{NH} 4 \mathrm{Cl}, \mathrm{H}_{3} \mathrm{BO}_{3}$, and saccharin. In the process of electrolysis, stainless steel metal used as the working electrode, a counter electrode in the form of platinum metal, and a comparative electrode in the form of $\mathrm{Ag} / \mathrm{AgCl} .5$ gram of $\mathrm{NaHCO}_{3}$ were dissolved in 1 liter of aquabides to be used as an electrolyte solution. Afterwards, the kersen leaves extract is added with a variety of concentrations. Variations in media concentration consisted of $0 \mathrm{~g} / \mathrm{ml} ; 0.2 \mathrm{~g} / \mathrm{ml} ; 0.04 \mathrm{~g} / \mathrm{ml}$; $0.008 \mathrm{~g} / \mathrm{ml} ; 0.0016 \mathrm{~g} / \mathrm{ml} ; 0.00032 \mathrm{~g} / \mathrm{ml}$; and 0.000064 $\mathrm{g} / \mathrm{ml}$. The determination of hydrogen gas efficiency uses voltammetry with the concentration variations of the media addition at temperatures of $25^{\circ} \mathrm{C}, 35^{\circ} \mathrm{C}, 45^{\circ} \mathrm{C}$ and a sweeping rate of $50 \mathrm{mV} / \mathrm{s}$.

Characteristics test for stainless steel electrode is done using XRD and SEM-EDX. The voltammogram data from the results of water electrolysis using the cyclic voltammetry method were calculated for the production efficiency by the equation:

$$
\varepsilon=\frac{i_{c} 35^{\circ} \mathrm{C}}{i_{c} 25^{\circ} \mathrm{C}} \mathrm{Xx} 100 \% \frac{i_{c} 45^{\circ} \mathrm{C}}{i_{c} 25^{\circ} \mathrm{C}}
$$

$$
\varepsilon=\frac{i_{c \text { media }}}{i_{c \text { non media }}} \times 100 \%
$$

Energy efficiency is calculated based on the equation:

$$
\Delta \mathrm{E}=\left(\mathrm{E}_{\text {eksperimen }}-\mathrm{E}_{\text {teori }}\right)
$$

\section{RESULT AND DISCUSSION}

\subsection{Characterization of Stainless Steel}

Characterization of stainless steel was fulfilled using SEM-EDX and XRD tools. Stainless Steel metal were tested using SEM-EDX at 5000x magnification. Based on research conducted by Isana (2012) obtained the morphology of stainless steel metal that can be seen in Figure 1.

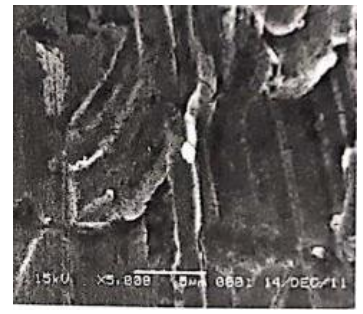

Figure 1. Stainless Steel Characterization Results with SEM

Figure 1 shows that the surface of the stainless steel looks smoother and flatter. The $\mathrm{Fe}, \mathrm{Co}$, and $\mathrm{Ni}$ elements contained in stainless steel metals are analyzed further using the EDX tool. Based on a research of Isana (2012), the content of Fe, Co, and $\mathrm{Ni}$ in stainless steel metal prior to coating through the electrodeposition process of $80.11 \% \mathrm{Fe} ; 0.05 \% \mathrm{Co}$; and $0.00 \% \mathrm{Ni}$ [6].

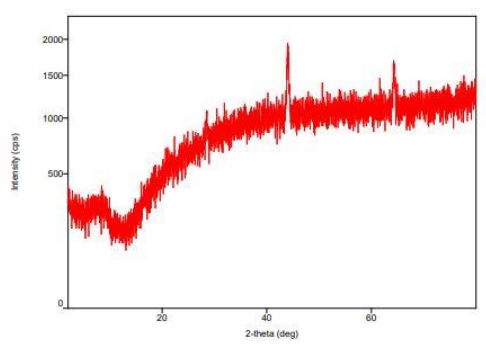

Figure 2. Results of XRD Characterization of Stainless Steel

At the stainless steel diffractogram there are several peaks with an angle of $2 \theta$ diffraction of $43.97^{\circ}$ and $63.97^{\circ}$ which indicate the metal phase of Fe and Co. Diffractogram XRD consists of multiple peaks with varying intensity and angle range of $2 \theta$. The magnitude of intensity is comparable to the number of X-ray photons detected for each angle. Peak positions depend on the sample structure tested so that the peak position can be used as an indicator in the determination of the structure and parameters of the material lattice [16]. 


\subsection{Water Electrolysis}

The working electrode activity namely stainless steel in hydrogen electro-generation was further investigated by the water electrolysis $\left(\mathrm{H}_{2} \mathrm{O}\right)$ method using the kersen leaves extract media. An electrolyte solution is needed in the water electrolysis process to reduce the energy and boost the reaction rate. The electrolyte solution used in this study was 5 grams of $\mathrm{NaHCO}_{3}$ solution per liter of solution. A research conducted by Jabar \& Ibrahim (2012) proves that the use of $\mathrm{NaHCO}_{3}$ solution in the hydrogen electro-generation process is better than the use of $\mathrm{NaOH}$.

The voltammogram curve shows the peak of the oxidation reaction or the peak of the anodic current $\left(I_{a}\right)$ and the peak of the reduction reaction or the peak of the cathodic current $\left(I_{c}\right)$ during the water electrolysis process. Anodic peak shows the amount of formed oxygen gas, while the cathodic peak shows the amount of formed hydrogen gas. Cyclic voltammogram of water electrolysis results from the testing of 7 samples can be seen in Figure 3.

$25^{\circ} \mathrm{C}$ Stainless Steel Voltammogram
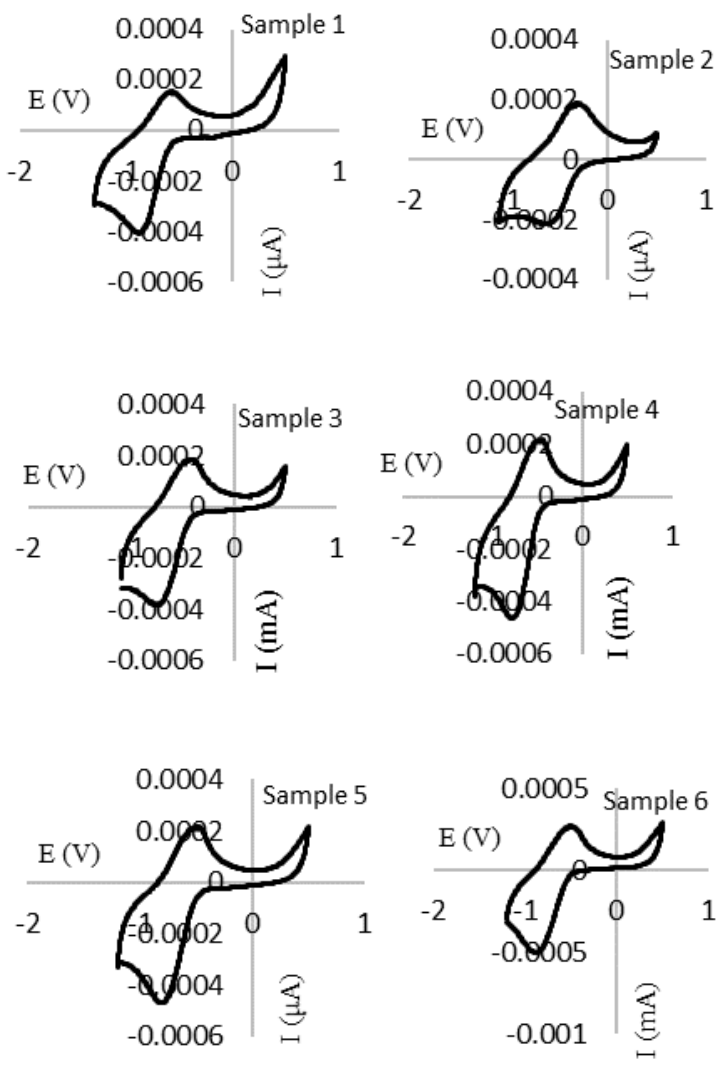

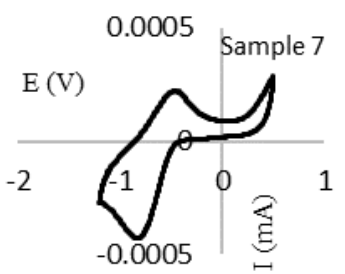

$35^{\circ} \mathrm{C}$ Stainless Steel Voltammogram
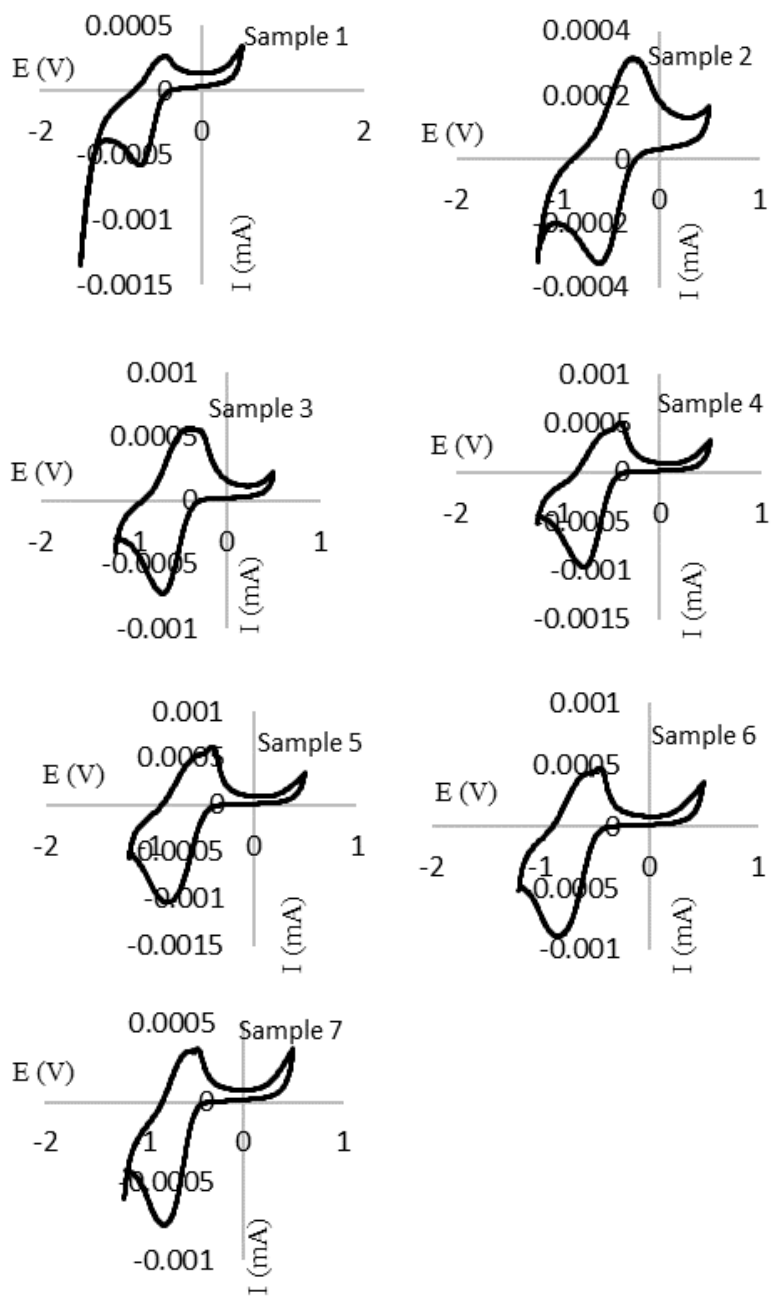

$45^{\circ} \mathrm{C}$ Stainless Steel Voltammogram

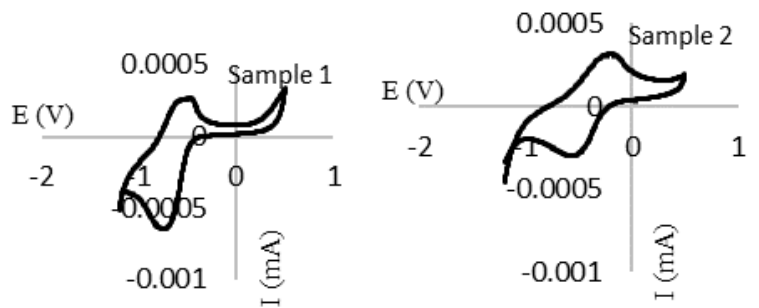



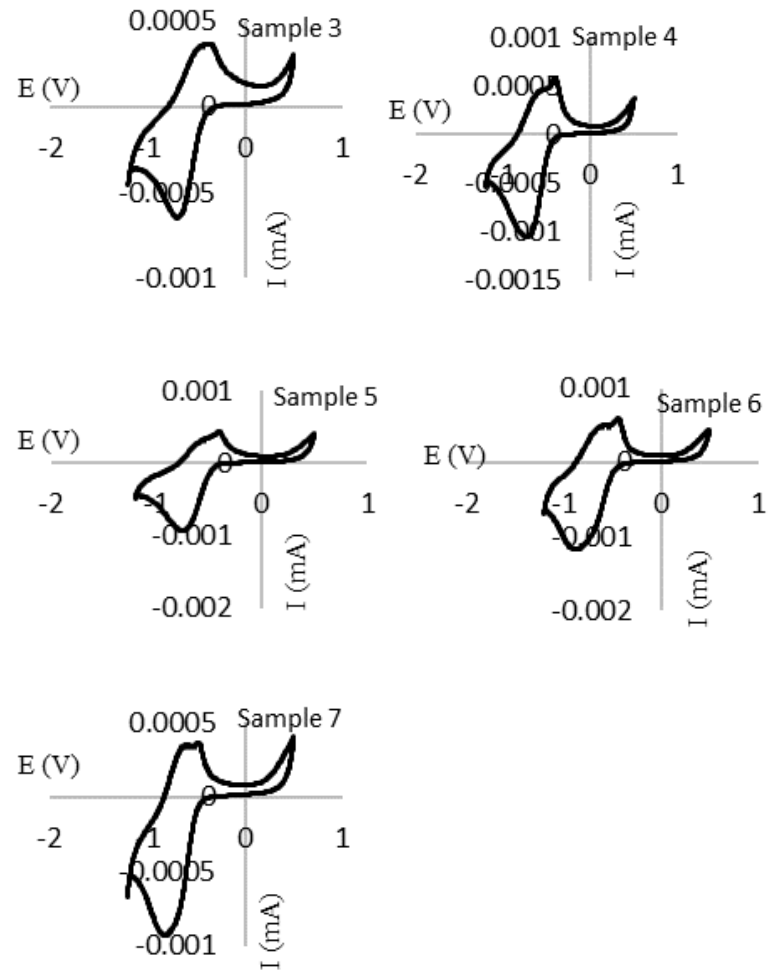

Figure 3. Cyclic voltammogram

The water electrolysis by voltammetry is based on the adsorption and desorption processes. The amount of produced hydrogen is indicated by the peak of the cathodic current $\left(I_{c}\right)$. The greater the value of $I_{c}$, the greater the amount of hydrogen gas produced during the water electrolysis process. Table 1 shows the best $I_{c}$ value for stainless steel electrode found at a treatment temperature of $45^{\circ} \mathrm{C}$. At $45^{\circ} \mathrm{C}$, the value of $I_{c}$ stainless steel electrodes was $-1.1806 \mathrm{~mA}$ in sample 6 . The data indicates that the catalytic activity of stainless steel electrodes in improving hydrogen gas production is best at the temperature treatment of $45^{\circ} \mathrm{C}$.

Table 1. Energy Efficiency and Cathodic Current Data Electrolysis Results using Electrode Stainless Steel

\begin{tabular}{|c|c|c|c|c|c|c|}
\hline \multirow{3}{*}{ Sample } & \multicolumn{6}{|c|}{ Stainless Steel Electrode } \\
\hline & \multicolumn{2}{|c|}{$25^{\circ} \mathrm{C}$} & \multicolumn{2}{|c|}{$35^{\circ} \mathrm{C}$} & \multicolumn{2}{|c|}{$45^{\circ} \mathrm{C}$} \\
\hline & Ic (mA) & $E(V)$ & Ic (mA) & $E(V)$ & Ic (mA) & $E(V)$ \\
\hline Sample 1 & -0.407 & -0.880 & -0.576 & -0.760 & -0.648 & -0.750 \\
\hline Sample 2 & -0.214 & -0.620 & -0.326 & -0.590 & -0.301 & -0.580 \\
\hline Sample 3 & -0.383 & -0.750 & -0.728 & -0.700 & -0.646 & -0.690 \\
\hline Sample 4 & -0.464 & -0.780 & -0.969 & -0.750 & -1.049 & -0.720 \\
\hline Sample 5 & -0.469 & -0.810 & -1.038 & -0.830 & -0.941 & -0.750 \\
\hline Sample 6 & -0.500 & -0.880 & -0.893 & -0.800 & -1.180 & -0.880 \\
\hline Sample 7 & -0.430 & -0.830 & -0.776 & -0.800 & -0.931 & -0.820 \\
\hline
\end{tabular}

The fluctuating peak value of cathodic currents is due to the covering on the electrode surface by the kersen leaves extract media. According to Isana et al.
(2015) organic compounds are able to bind to the metal on the surface of the electrode and form a chelate which causes the closure of the active site on the surface of the electrode [11]. In result, it disrupts the work of the electrode and obstructs the electrolysis process.

\subsubsection{Over-potential}

The smaller the over-potential value, the smaller the energy needed in the hydrogen electro-generation process. The results of energy efficiency can be seen in table 2 .

Table 2. Over-potential Values in the Water Electrolysis Process

\begin{tabular}{|l|c|c|c|}
\hline \multirow{2}{*}{ Sample } & \multicolumn{3}{|c|}{ Over-potential } \\
\cline { 2 - 4 } & $\mathbf{2 5 ^ { \circ } \mathrm { C }}$ & $\mathbf{3 5}^{\circ} \mathrm{C}$ & $\mathbf{4 5}^{\circ} \mathrm{C}$ \\
\hline Sample 1 & 0.052 & 0.068 & 0.078 \\
\hline Sample 2 & 0.208 & 0.238 & 0.248 \\
\hline Sample 3 & 0.078 & 0.128 & 0.138 \\
\hline Sample 4 & 0.048 & 0.078 & 0.108 \\
\hline Sample 5 & 0.018 & 0.002 & 0.078 \\
\hline Sample 6 & 0.052 & 0.012 & 0.052 \\
\hline Sample 7 & 0.002 & 0.028 & 0.008 \\
\hline
\end{tabular}

Based on Table 2, the smallest over-potential value gained from those electrodes is 0.002 volts, means that the energy needed for water electrolysis is only 0.002 volt. If the average value of the over-potential stainless steel electrode at $25^{\circ} \mathrm{C}$ is obtained 0.065 volt, at a temperature of $35^{\circ} \mathrm{C}$ the average over-potential value is 0.079 volt, and the average over-potential value of 0.101 volt at $45^{\circ} \mathrm{C}$. Based on these values, stainless steel electrodes require more energy when temperature treatment is improved.

\subsubsection{The efficiency of hydrogen gas production}

The efficiency of hydrogen gas production can be determined based on the influence of temperature and media. The efficiency of hydrogen gas production in terms of the influence of the temperature can be seen in Figure 4.

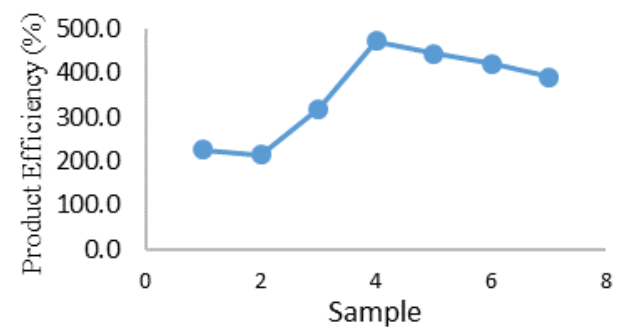

Figure 4. Efficiency of Hydrogen Gas Production Based on Temperature Effect

Based on Figure 4, stainless steel electrodes has the highest production efficiency in sample 4 with $472 \%$ 
percentage and an over-potential value of 0.048 volts. It means that stainless steel electrodes only need 0.048 volt of energy to produce $472 \%$ hydrogen gas thus it significantly influences the efficiency of hydrogen gas production.

Another factor affecting the efficiency of hydrogen gas production is the media influence. The results of the efficiency of hydrogen gas production based on the media influence can be seen in Figure 5.

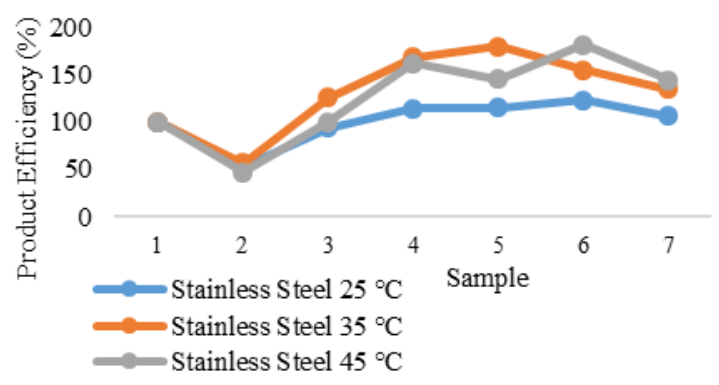

Figure 5. Efficiency of Hydrogen Gas Production Based on the Effect of Media on Electrodes Stainless Steel

Figure 5 shows that the adding of media on the hydrogen gas production efficiency using stainless steel electrodes with a temperature treatment of $25^{\circ} \mathrm{C}$ produced the highest percentage in sample 6 with $122,82 \%$ percentage which requires energy of 0.018 volts. In sample 5 with a temperature of $35^{\circ} \mathrm{C}$ produced a product efficiency of $180 \%$ with an over-potential value of 0.002 volts. In sample 6 with a temperature of $45^{\circ} \mathrm{C}$ requires 0.052 volts to produce a product efficiency of $182 \%$. When reviewed from the entire data, the addition of media to the water molecular breakdown process $\left(\mathrm{H}_{2} \mathrm{O}\right)$ significantly affects the amount of hydrogen produced.

\subsubsection{Optimum Condition}

The optimum conditions can be determined based on the smallest energy usage to produce the greatest product efficiency. Based on the overall research data, the optimum condition is found in Sample 4 which requires only 0.048 volts to produce a hydrogen gas of $472 \%$ and optimum temperature treatment at $45^{\circ} \mathrm{C}$.

\section{CONCLUSION}

The addition of the kersen leaves extract media in the water electrolysis process using stainless steel electrodes can increase hydrogen gas production. Hydrogen gas is produced more at $45^{\circ} \mathrm{C}$ than it is at $25^{\circ} \mathrm{C}$ and $35^{\circ} \mathrm{C}$. Hydrogen gas production using the water electrolysis method obtained optimum results at the concentration of the kersen leaf extract media by $0.008 \mathrm{~g} / \mathrm{ml}$ and a temperature condition of $45^{\circ} \mathrm{C}$.

\section{REFERENCES}

[1] Anam, K., \& Susilaningsih, D. 2015. Hydrogen Production Using Rhodobium marinum In Milk 38(1), 1-8. https://doi.org/10.14203/jti.v38i1.118.

[2] Dewi, E. L. 2011. Potensi Hidrogen sebagai Bahan Bakar untuk Kelistrikan Nasional. Prosiding Seminar Nasional Teknik Kimia "Kejuangan" Pengembangan, 1-6.

[3] Fahreza, D., Kurniawati, D., \& Subeki, N. 2018. Analisis Produksi Gas Hidrogen Dan Gas Oksigen. 2017, 50-54.

[4] Isana, SYL. 2007. Variasi Suhu dan Waktu Sel Elektrolisis Berbagai Merk Minuman dengan Elektroda Karbon. Laporan Penelitian. DIPA UNY, UNY, Yogyakarta.

[5] Isana, SYL. 2009. Variasi Temperatur dan Waktu pada Elektrolisis Larutan Garam Dapur Berbagai Merk. Seminar Nasional Kimia. Jurusan Pendidikan Kimia FMIPA UNY pada tanggal 17 Oktober 2009.

[6] Isana, SYL. 2012. Studies on the Hydrogen Evolution Reaction on Fe-CoNi/Stainless Steel Electrode. IOSR Journal of Applied Chemistry. https://doi.org/10.9790/5736-0310610.

[7] Isana, SYL., Endang Widjajanti Laksono, Dewi Yuanita Lestari. 2019. Comparison Study Of Stainless Steel Cyclic Voltammograms In Various Natural Media Addition: Product And Voltage Efficiency. 20(2), 0-10.

[8] Isana, SYL., H. P. Aloysius, S. Sulistyani. 2020. The efficiency of hydrogen production by water electrolysis with bitter melon as a media using stainless steel / $\mathrm{Fe}$-Co-Ni electrodes The efficiency of hydrogen production by water electrolysis with bitter melon as a media using stainless steel / FeCo-Ni electrodes. $0-7$. https://doi.org/10.1088/1742-6596/1442/1/012050.

[9] Isana, SYL., Suyanta, Laksono, E. D. 2020. Electrochemical Production of Hydrogen in Fermented Flour by Stainless Steel Electrode. Asian Journal of Chemistry, Vol. 32, No. 4, 2020 Hal: 835-838.

[10] Isana, SYL., Yuanita, D., \& Al, H. P. 2017. Voltammogram of Stainless Steel / $\mathrm{Fe}-\mathrm{Co}-\mathrm{Ni}$ Electrode on Water Electrolysis in Base Condition with Dahlia Pinnata Tuber Starch Media. 020011. https://doi.org/10.1063/1.4995097.

[11] Isana, SYL., Yuanita, D., \& Pratomo, H. 2015. Pemecahan Molekul Air Dengan Menggunakan Media Tepung Umbi Dahlia (Dahlia pinnata). Jurnal Sains Dasar.

[12] Jabar, S. N. B., \& Ibrahim, M. Z. 2012. The effect of $\mathrm{NaHCO}_{3}$ as catalyst via electrolysis. Oriental Journal of Chemistry. https://doi.org/10.13005/ojc/280305.

[13] Kholiq, I. 2012. Editorial Board. Current Opinion in Environmental Sustainability, 4(1), i. https://doi.org/10.1016/s1877-3435(12)00021-8. 
[14] Kuntorini, E. M. S. F. dan M. D. A. 2013. Struktur Anatomi dan Uji Aktivitas Antioksidan Ekstrak Metanol Daun Kersen (Muntingia calabura). Prosiding Semirata. Lampung: FMIPA Universitas Lampung.

[15] Mazloomi, S. K., \& Sulaiman, N. 2012. Influencing factors of water electrolysis electrical efficiency. Renewable and Sustainable Energy Reviews, 16(6), 4257-4263. https://doi.org/10.1016/j.rser.2012.03.052.

[16] Sutopo, W. 2017. Produksi Gas Hidrogen Melalui Pemecahan Molekul H2O Menggunakan Elektroda Stainless Steel/Fe-Co-Ni Dalam Media Tepung Daun Sukun. Skripsi. FMIPA UNY.

[17] Yufita, E., \& Fitriana, D. 2018. Pengendalian Laju Korosi Pada Baja Plat Hitam a36 Dalam Medium Korosif Menggunakan Inhibitor Ekstrak Daun Salam Control of Corrosion Rate on a36 Black Plate Steel in Corrosive Medium Using Salam Leaf. Journal of Aceh Physics Society, 7(2), 67-71. 